Veterinary Serum and Vaccine Research Institute, Abbasia, Cairo, Egypt

Central Veterinary Diagnostic Lab, Ministry of Agriculture, Riyadh. KSA.

\title{
EPIDEMIOLOGICAL STUDIES OF T. EVANSI IN \\ CAMELS IN SAUDI ARABIA USING REAL TIME POLYMERASE CHAIN REACTION TECHNIQUE
}

(With One Table and Two Figures)

\section{By}

\section{R.M. AL-KHATIB; M.R. YOUSEF and H.M. AL NAKHLI*}

* National Agriculture and Animal Resources Research Center,

Ministry of Agriculture, Riyadh. KSA.

(Received at 13/6/2011)

دراسات وبائية على التريبانوسوما ايفانساى في الإبل بالمملكة العربية

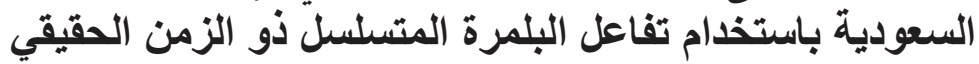

رجب محمد الخطيب ، محمد ربيع بيوسف ، حبيب مقبول المناخلى

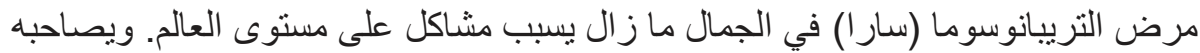

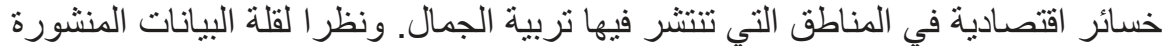

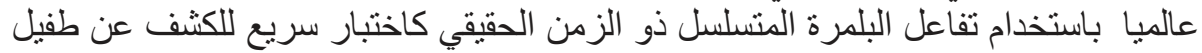

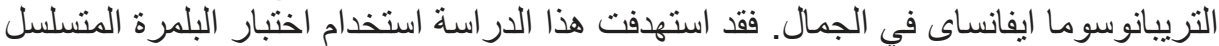

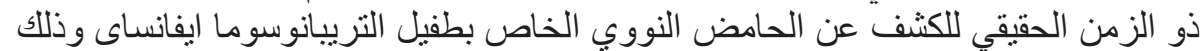

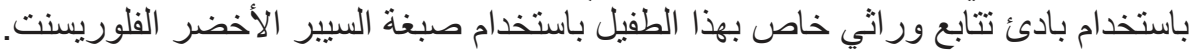

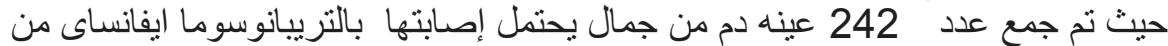

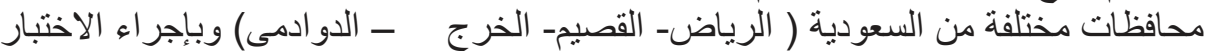

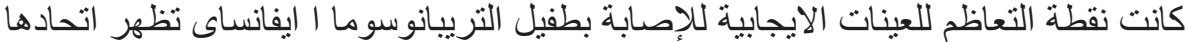

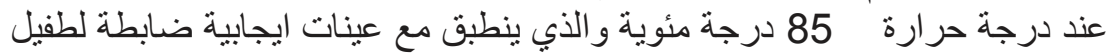

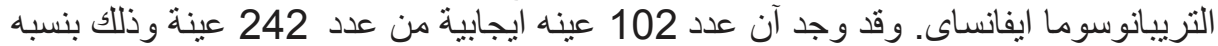

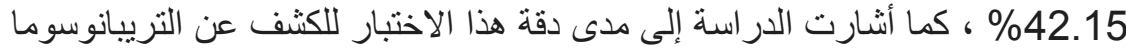

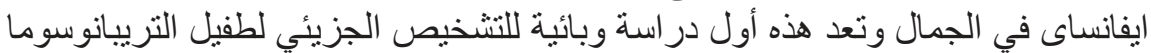

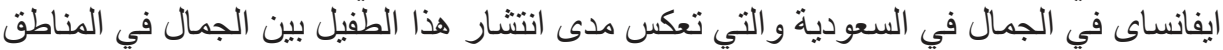

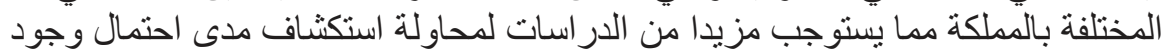
أنو اع أخرى من هذا الطفيل وكذللك محاولة السيطرة على الإصابة بهذه الطفيليات بالمملكة. 
Trypanosomasis (surra) still a serious problem in camel husbandry world widly. It causes considerable economic losses in many camel-rearing regions. A little date for Real Time polymerase chain reaction (PCR) for rapid detection Trypanosoma evansi of blood from naturally infected camels were puplished. In the present study 242 blood samples from clinically suspected camels to surra from four province of Saudia (AlRiyadh, Al- Qassim, Alharig, and Al-Dawadmi) were collected and used for further examination. Real Time PCR-based assay for blood samples were conducted in direct detection of $T$. evansi DNA from the collected blood samples using specific primer set (TR3/TR4) derived from nuclear repetitive gene of T.evansi and SYBER Green1 fluorescent dye have been used. The melting peak chart of the positive samples showed one single peak at an average $\mathrm{Tm}$ of $85.0^{\circ} \mathrm{C}$. The performed real time PCR technique was found accurate method for diagnosis of trypanosoma infection of camels where; 102 (42.15\%) out of 242 were positive. It is concluded that camel trypanosomiasis in Sudia apparently caused by the present single parasite species $T$. evansi and detection of other typanosomes species are recommonded. In addition, the disease is highly prevalent in the country, which strengthens the need to change control policies and institute measures that help prevent the spread of the parasite. To our knowledge, this is the first molecular diagnosis report, which gives a picture of camel trypanosomiasis covering large geographical areas in Saudi Arabia.

Key words: Camels, Real time PCR, SYBER Green1, Trypanosoma evansi,.

\section{INTRODUCTION}

Trypanosomasis ('surra') caused by Trypanosoma evansi is considered to be one of most important diseases of camels in KSA. Trypanosoma evansi is the most widely geographically distributed pathogenic trypanosome. It can infect several species of animals, including, camels, horses, cattle and buffaloes causing trypanosomosis commonly known as surra (Luckins, 1988). Trypanosoma evansi (T. evansi), the cause of trypanosomiasis (Surra), constitutes one of the major veterinary problems worldwide. The disease causes significant morbidity and mortality in camels (Pathak, and Khanna, 1995; Omer et al., 2004). Surra, manifests itself usually as a chronic infection characterized by weight loss, anemia, infertility and abortion (Lohr et al., 1986; Luckins, 1988). Trypanosoma evansi is a blood-borne 
parasite that is transmitted mechanically by the bites of haematophagous flies. Initially, trypanosomes may be seen readily in the bloodstream, but in chronic infections parasites are difficult or impossible to find (Luckins, 1988) and in chronic infections is likely to be associated with secondary infections due to immunosuppression (Njiru et al., 2004). Clinical signs and pathological lesions caused by $T$. evansi in camels are unreliable for definitive diagnosis (Chaudhary and Iqbal, 2000) in addition, detection of parasites in the blood is difficult because parasitaemia is intermittent (Mahmound and Gray, 1980). Serological tests have been developed and evaluated for diagnosis of trypanosomiasis in camels. They include card agglutination test and enzyme-linked immunosorbent assay (Ab-ELISA) (Nantulya, 1994; Davison et al., 1999). In general serological techniques are useful for detection of a past infection but not for detection of an active infection with T. evansi (Viseshakul and Panyim 1990; Hopkins et al., 1998). To address these problems; Real time polymerase chaine reaction technique have been developed and evaluated for detection of $T$. evansi directly from blood (Wuyts et al., 1995; Omawa et al., 1999; Imadeldin et al., 2006; Yousef et al., 2010). In Saudia, camels a principal mean of meat and milk production, they are used for transportation of crops and do other farm works; also, their hair, wool and hides are used. Trypanosomosis in camels causes considerable economic losses due to a decrease in milk and meat, premature births and abortions (Boid et al., 1985). In-sight the aim of this study was planed to explore the rate of $T$. evansi among camel population in giving four different provinces in KSA by the most resent molecular technique; real time PCR as a preliminary step for designing rational trypanosomiasis control program.

\section{MATERIALS and METHODS}

\section{Animals}

This study was Realized from May 2010 to April 2011; a total number of 242 suspected clinical camels (Camelus dromedarius), 3-8 years old, were examined clinically: body temperature, mucous membrane, muscles of thigh and hump. These animals were located in four province in Saudia (Al- Riyadh, Al- Qassim, Alharig and AlDawadmi). The main complaints of the camel owners were loss of appetite, decrease of productivity, and reduce of the body weight. 


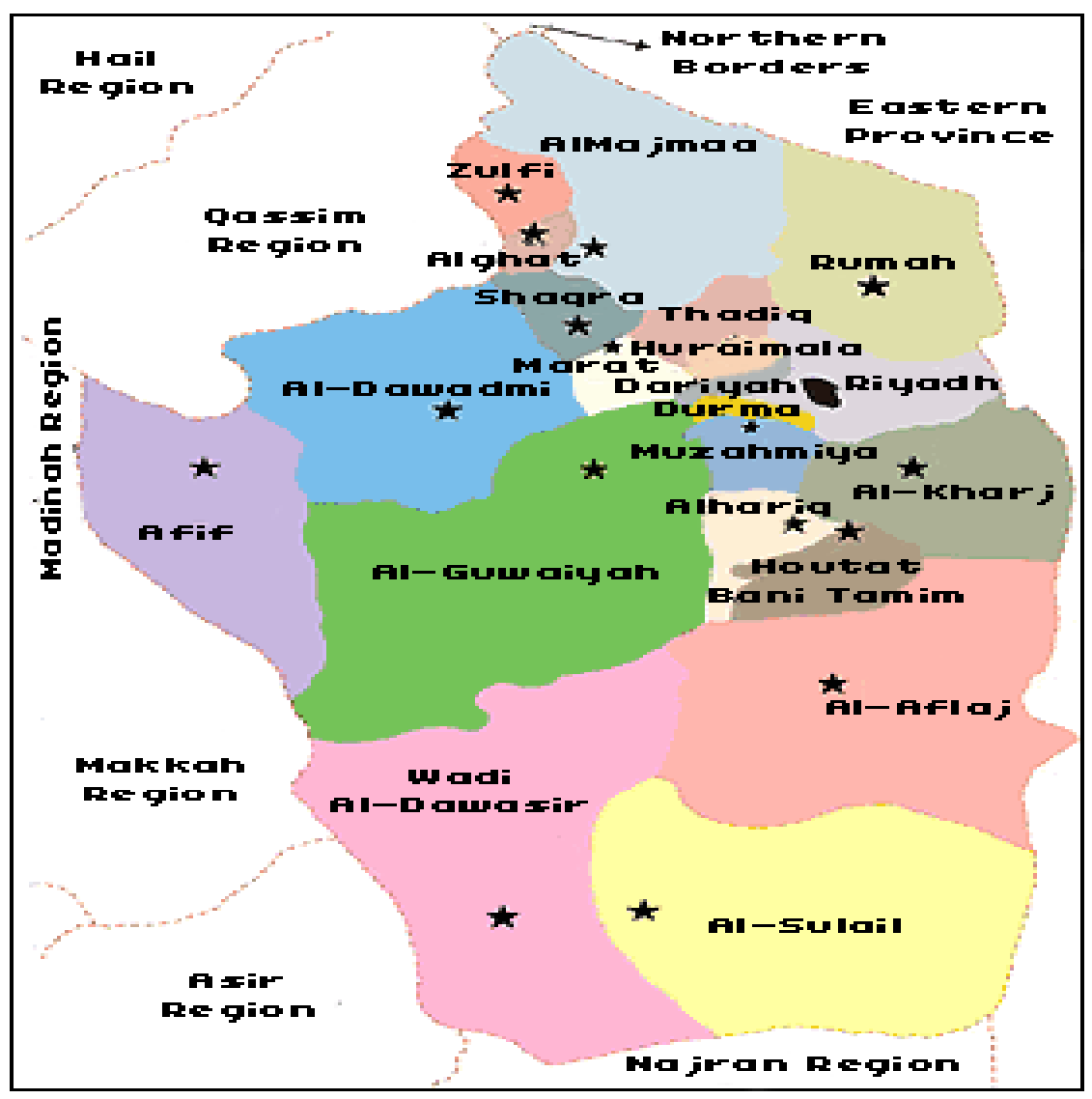

Fig. 1: Map of Al Riyadh showing study Provinces

\section{Blood samples}

Blood samples were collected in clean sterile vacationers, containing ethylene diamine tetra acetic acid (EDTA), from naturally suspected infected camels.

\section{Extraction of DNA from blood samples:}

Automated extraction of total genomic DNA from the whole blood by BioRobot EZ1 workstation (Qiagen $®$ ) using EZ1 DNA blood kit (Qiagen $\left.{ }^{\circledR}\right)$ according to the manufacturer's instructions.

\section{Primers:}

T.evansi repetitive DNA primers was designed and synthesized in BiolegioBV®, Belgium to amplify a single band of $257 \mathrm{bp} \mathrm{PCR}$ product according to Chansiri et al. (2002); Yousef et al. (2010) for RTPCR:

TR3 (5' GCGCGGATTCTTTGCAGACGA 3') 


\section{TR4 (5' TGCAGACACTGGAATGTTACT 3')}

\section{Real times PCR assay:}

Polymerase chain reaction was carried out in LightCycler 2.0 (Roach $\left.{ }^{\circledR}\right)$.The PCR mixture $(20 \mu \mathrm{l})$ contained $15 \mu$ l of reaction mixture containing Fast start DNA Master ${ }^{\text {plus }}$ SYBER Green 1(Roach $\left.{ }^{\circledR}\right)$ and 10 pmoll $\mu 1$ concentration of each primer and $5 \mu 1$ of genomic DNA. The PCR profile was performed as following; pre-heated for 1 cycle at $90{ }^{\circ} \mathrm{C}$ for $10 \mathrm{~min}$ and then denatured at $94{ }^{\circ} \mathrm{C}$ for $5 \mathrm{sec}$, annealing at $55^{\circ} \mathrm{C}$ for $10 \mathrm{sec}$ and extension at $72{ }^{\circ} \mathrm{C}$ for $10 \mathrm{sec}$. The PCR amplification was performed for 45 cycles. Fluorescence data were acquired at the end of each cycle in a single step. Once the plateau phase of the PCR had been reached, amplification was stopped and a standard melting curve analysis was performed $\left(95^{\circ} \mathrm{C}\right.$ for 0 second, $65^{\circ} \mathrm{C}$ for 10 seconds, and a $0.1^{\circ} \mathrm{C} /$ second rise to $95^{\circ} \mathrm{C}$ ) with continual fluorescence measuring. PCR data were analyzed using LightCycler2 software version 4.05.

\section{RESULTS}

Table 1: The percentages of positives from four provinces in Saudi.

\begin{tabular}{|c|c|c|c|}
\hline Province & $\begin{array}{c}\text { No. of } \\
\text { examined } \\
\text { animals }\end{array}$ & $\begin{array}{c}\text { No. of } \\
\text { positive }\end{array}$ & $\begin{array}{c}\text { \% of positive } \\
\text { to total examined }\end{array}$ \\
\hline Al- Riyadh & 80 & 25 & 10.33 \\
\hline Al- Qassim & 70 & 41 & 16.94 \\
\hline Alharig & 60 & 31 & 12.81 \\
\hline Al-Dawadmi & 32 & 5 & 2.07 \\
\hline $\begin{array}{c}\text { Total } \\
\text { examined }\end{array}$ & 242 & 102 & 42.15 \\
\hline
\end{tabular}

The melting peak chart of the positive samples showed one single peak at an average $\mathrm{Tm}$ of $85.0^{\circ} \mathrm{C}$. (Fig.2).

The results of examined camels using real time PCR for detection of DNA of trypanosomes in suspected camels, showing a $102(42.15 \%)$. positive camels out of 242. The percentages of positives in different provinces as shown in Table (1) in Al- Riyadh, Al- Qassim, Alharig, and Al-Dawadm are 10.33\%, 16.94\%, $12.81 \%$ and $2.07 \%$ respectively. 


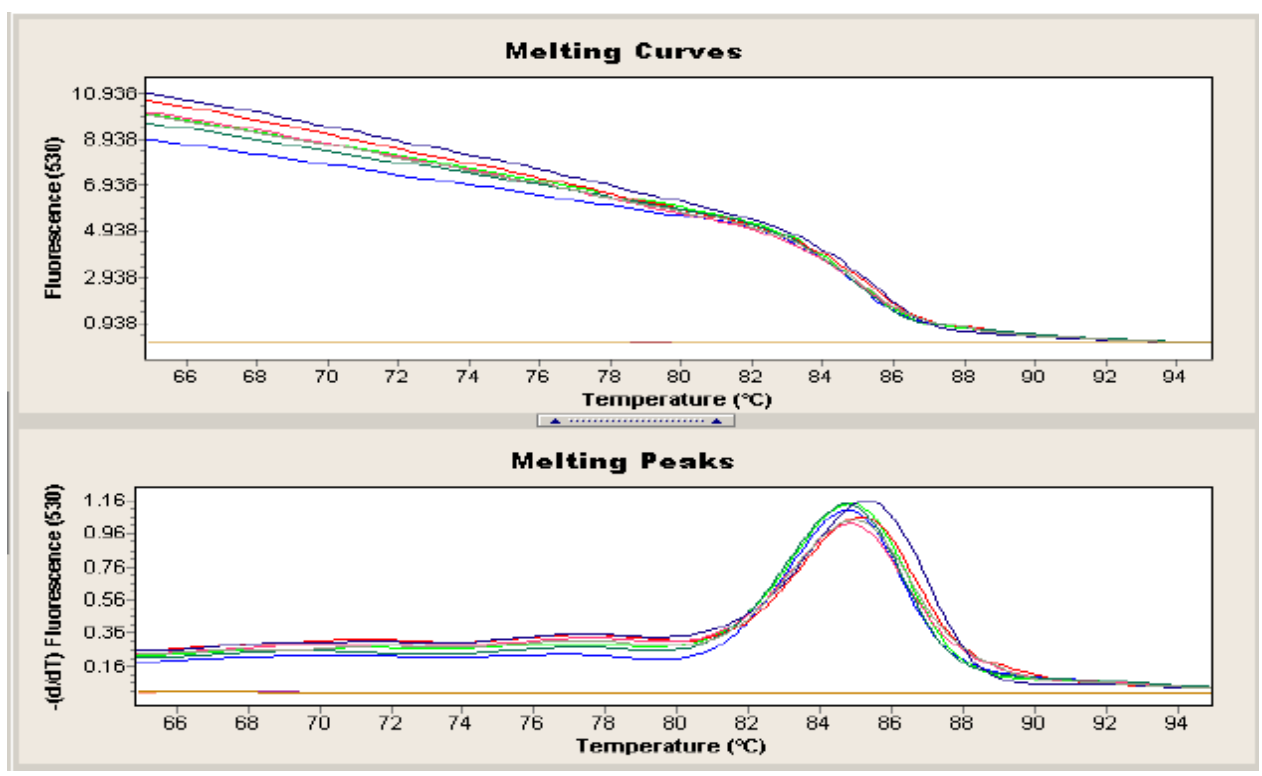

Fig. 2: Melting curve analysis of amplicon obtained from real time PCR.

\section{DISCUSSION}

The economic importance of $T$. evansi infection is mainly attributed to clinical disease in camels in many parts of the world (Dia et al., 1997; Atarhouch et al., 2003). The fact that PCR assays provided evidence of infection in animals that were classified as uninfected by parasitological techniques suggests that PCR could have an important role to play in the detection of infected animals harbouring a low parasitaemia that would be undetectable by smears (Chansiri et al., 2002; Bashir et al., 2011).

The better PCR sensitivity and the fact that samples can be taken as blood spots on filter papers open the opportunity to carry out epidemiological studies in remote regions in countries where accessibility and conditions to store samples are really difficult, Sample processing in PCR does not have to be done within minimum time after collection but can be delayed at least 180 days after preservation at $20^{\circ} \mathrm{C}$ (Clausen et al., 1998). The main advantages of different PCR assays are very low false-positives and insensitive to other haemoparasite species (Chansiri et al., 2002). Conventional PCR (Omer et al., 1998; Guterrez et al., 2000; Masiga and Nyang'ao 2001; Bashir et al., 2011) and real time PCR (Yousef et al., 2010.) has been used successfully for detecting of infection with $\mathrm{T}$. evansi in camels. 
The real time PCR technique as used in this study was able to detect the suspected acute and chronic infection of T. evansi and may be the low parasitaemia consistently a new, sensitive and rapid diagnostic technique.

The obtained result $(42.15 \%)$ was similar to that recorded in Kenya; 39.8\% (Njiru et al., 2004) and $34.40 \%$ in India (Reghu et al., 2008) but higher than that recorded in India (17.05\%) and Kenya (26.6\%) (Singh et al., 2004; Njiru et al., 2004), but lower than that in Sudan $(57.1 \%)$ (Bashir et al., 2011). The improved detection rates found in the present study, was also reported in studies carried out in the Brazilian pantanal (Ventura et al., 2001; Ventura et al., 2002): these may be attributed to selection of assay conditions and primer sets being used. Our results also revealed that the real time PCR assay was beneficial for diagnosis of $T$. evansi among camels and could be useful for epidemiological, following of drug treatment study and designing rational trypanosomiasis control program in the endemic area.

It is concluded that camel trypanosomiasis in Sudai is apparently caused by a single parasite species $T$. evansi and there were no other typanosomes species detected. In addition, the disease is highly prevalent in the country, which strengthens the need to change control policies and institute measures that help prevent the spread of the parasite. To our knowledge, this is the first molecular diagnosis report, which gives a picture of camel trypanosomiasis covering large geographical areas in Sudai Arabia.

\section{REFERENCES}

Atarhouch, T.; Rami, M.; Bendahman, M.N. and Dakkak, A. (2003): Camel trypanosomosis in Morocco 1: results of a first epidemiological survey. Vet. Parasitol. 111: 277-286.

Bashir Salim.; Mohammed A Bakheit; Joseph Kamau; Ichiro Nakamura and Chihiro Sugimoto (2011): Molecular epidemiology of camel trypanosomiasis based on ITS1 rDNA and RoTat 1.2 VSG gene in the Sudan.

Boid, R.; Jones, T.W. and Luckins, A.G. (1985): Protozoal diseases of camels. Brit. Vet. J., 141: 87-105.

Chansiri, K.; Khuchareontaworn, S. and Sarataphan, N. (2002): PCRELISA for diagnosis of T.evansi in animals and vector. Molecular and Cellular Probes 16: 173-177. 
Chaudhary, Z.I and Iqbal, M.J. (2000): Incidence, biochemical and haematological alterations induced by natural trypanosomosis in racing dromedary camels. Acta Trop 77: 209-213.

Clausen, P.-H.; Wiemann, A.; Patzelt, R.; Kakaire, D.; Poetzsch, C.; Peregrine, A. and Mehlitz, D. (1998): Use of a PCR assay for the specific and sensitive detection of Trypanosoma spp. In naturally infected dairy cattle in peri-urban Kampala, Uganda Ann. N.Y. Acad. Sci. 849: 21-31.

Davison, H.C.; Thrusfield, M.V.; Muharsini, S.; Hussein, A.; Partoutomo, S.; Rae, P.F.; Masake, R. and Luckins, A.G. (1999):

Evaluation of antigen and antibody detection tests for Trypanosoma evansi infection of buffaloes in Indonesia. Epidemiol Infect. 123: 149-155.

Dia, M.L.; Diop, C.; Aminetou, M.; Jacquiet, P. and Thiam, A. (1997):

Some factors affecting the prevalence of Trypanosoma evansi in camels in Mauritania. Vet. Parasitol. 72: 111-120.

Guterrez, C.; Juste, M.C.; Corbera, J.M.; Magnus, E.; Verloo, D. and Montoya, J.A. (2000): Camel trypanosomosis in the Canary Island; assessment of seroprevalence and infection rate using the card agglutination test (CATT/ T. evansi) and parasite detection. Vet. Parasitol. 90: 15-9.

Hopkins, J.S.; Harrison, C.; Noreen, M.; Luckins, A.G.; Rae, P.E.; Bossche, P. and Eisler, M.P. (1998): Adaptation and validation of antibody - ELISA using dried blood spots on filter paper for epidemiological surveys of tsetse transmitted trypanosomosis in cattle. Preventive Veterinary Medicine, 37: 91-99.

Imadeldin E. Aradaib and Ali A. Majid (2006): A simple and rapid method for detection of Trypanosoma evansi in the dromedary camel using a nested polymerase chain reaction. Kinetoplastid Biol. Dis. 5: 2.

Lohr, K.F.; Pholpark, S.; Siriwan, P.; Leesirikul, N.; Srikitjakarn, N. and Staak, L.C. (1986): Trypanosoma evansi infection in buffaloes in north east Thailand. 2. Abortions. Trop. Anim. Hlth. Prod. 18: 103-108.

Luckins, A.G. (1988): Trypanosoma evansi in Asia. Parasitol Today 4: 137-142.

Mahmound, M.M. and Gray, A.R. (1980): Trypanosomosis due to T. evansi.A review of recent research. Trop. Anim. Health Prod. 12: $35-47$.

Masiga, R.C. and Nyang'ao, J.M. (2001): Identification of trypanosome 
species from camel using polymerase chain reaction and procyclic transformation test. Camel Pract. Res. 8: 17-22.

Nantulya, V.M. (1994): Suratex®: A simple latex agglutination antigen test for diagnosis of Trypanosoma evansi (Surra). Trop. Med. Parasitol. 45: 9-12.

Njiru, Z.K.; Constantine, C.C.; Ndung'u, J.M.; Robertson, I.; Okaye, S.; Thompson, R.C.A. and Reid, S.A. (2004): Detection of Trypanosoma evansi in camels using PCR and CATT/T. evansi tests in Kenya. Vet. Parasit. 124(3-4): 187-99.

Omawa, S.; Rao, J.R.; Basagoudanavar, S.H.; Singh, R.H. and Butchaiah, G. (1999): Direct and sensitive detection of Trypanosoma evansi by polymerase chain reaction. Acta. Vet. Hung. 47: 351-59.

Omer, R.A.; Elamin, S.M.M.; El Nahas, A.E. and Aradaib, I.E. (2004): PCR for detection of Echinococus granulosus hydatid cysts collected from camels (Camelus dromerarius) The Sudan. J. of Vet. Sci. and Anim. Husbandry. .43:139-143.

Omer, OH.; Magzouls, M.; Haroun, E.M.; Mahmoud, O.M. and Abdel Hamid, Y.M. (1998): Diagnosis of Trypanosoma evansi in Saudi Arabian camels (Camelus dromedorius) by the passive haemagglutination teat and Ag- ELISA. Zentralbl Veterinarmed. 45: 627-33. Parasites and Vectors. 4:31.

Pathak, K.M.L. and Khanna, M.D. (1995): Trypanosomiasis in camel with particular reference to Indian subcontinent: A Review. International J. Anim. Sci, 10: 157-162.

Reghu Ravindran, 1.; Jammi Raghavendra Raol; Ashok Kumar Mishral, Satheesh, and Sachivothaman Rahul5 (2008): Trypanosoma evansi in camels, donkeys and dogs in India: comparison of PCR and light microscopy for detection - short communication. Vet. Arhiv. 78 (1): 89-94.

Singh, N.; Pathak, K.M. and Kumar, R. (2004): A comparative evaluation of parasitological, serological and DNA amplification methods for diagnosis of natural Trypanosoma evansi infection in camels. Vet. Parasitol. 30, 126(4): 365-73.

Ventura, R.M.; Paiva, F.; Silva, R.A.M.S.; Takeda, G.; Buck, G.A. and Teixeira, M. (2001): Trypanosoma vivax: characterisation of the spliced - leader gene of a Brazilian stock and species - specific detection by PCR amplification of and intergenic spacer 
sequence. Experimental Parasitology. 99: 37-48.

Ventura, R.M.; Takeda, G.F.; Silva, R.A.M.S.; Nunes, V.L.B.; Buck, G.A. and Teixeira, $M$. (2002): Genetic relatedness among Trypanosoma evansi stocks by random amplification of polymorphic DNA and evaluation of a synapomorphic DNA fragment for species - specific diagnosis. International Journal for Parasitology. 32: 53-63.

Viseshakul, N. and Panyim, S. (1990): Specific DNA probe for the sensitivity detection of Trypanosoma evansi, Southeast Asian. J Trop. Med. Public. Health, 21: 21-27.

Wuyts, N.; Chokesajjawatee, N.; Sarataphan, N. and Panyim, S. (1995): PCR amplification of crude blood on microscope slides in the diagnosis of Trypanosoma evansi infection in dairy cattle Ann Soc. Belg. Med. Trop.75: 229-37.

Yousef, M.R.; Al-Khatib, R.M.; Mazloum, K.S.; Al-Sukayran, A. and Al Nakhli, H.M. (2010): Detection of Trypanosoma evansi in camels using SYBER Green1 real time PCR assay. Assiut Vet. Med. J. 56 (127): 279-287. 